\title{
TEMPOROMANDIBULAR JOINT DISORDER IN PATIENTS WITH PARKINSON'S DISEASE - A PILOT STUDY
}

\section{ZESPÓŁ ZABURZEŃ CZYNNOŚCI STAWU SKRONIOWO-ŻUCHWOWEGO U PACJENTÓW Z CHOROBĄ PARKINSONA - BADANIE PILOTAŻOWE}

\author{
Petra Baumann ${ }^{1(A, B, D, F)}$, Anna Sági ${ }^{2(B, E)}$, Beatrix Perjés ${ }^{2(B, F)}$, Viktória Prémusz ${ }^{2(D, E, F)}$, \\ Pongrác Ács ${ }^{2(A, B, C, D, E, G)}$, Gyula Marada ${ }^{1(A, B, D, E)}$, Norbert Kovács ${ }^{3(A, B, D, E)}$, Márta Radnai ${ }^{1(A, B, C, D, E, F)}$
}

${ }^{1}$ Department of Dentistry, Oral and Maxillofacial Surgery, Medical School, University of Pécs, Hungary

${ }^{2}$ Faculty of Health Sciences, University of Pécs, Hungary

${ }^{3}$ Department of Neurology, Medical School, University of Pécs, Hungary

Authors' contribution Wkład autorów:

A. Study design/planning zaplanowanie badań B. Data collection/entry zebranie danych

C. Data analysis/statistics dane - analiza i statystyki D. Data interpretation interpretacja danych E. Preparation of manuscript przygotowanie artykułu F. Literature analysis/search wyszukiwanie i analiza literatury G. Funds collection zebranie funduszy
Tables: 4

Figures: 1

References: 23

Submitted: 2020 Jul 17

Accepted: 2020 Aug 24

\section{Summary}

Background. The number of patients with temporomandibular joint disorders (TMD) is increasing in clinical dental practice. Our study aimed to determine whether a correlation between Parkinson's disease and TMD symptoms can be established.

Material and methods. The anamnestic and clinical dysfunctional indices and the correlations related to the quality of life (SF 36, QoL) of Parkinson's disease patients (PG, n=35) and healthy controls (CG, $\mathrm{n}=42$ ) were examined in a cross-sectional study. Statistical analysis was carried out using SPSS 24.0 software.

Results. The mean value (7.0 \pm 7.7$)$ of the PG in the OHIP-14 (Oral Health Impact Profile) questionnaire was significantly higher $(p<0.001)$ than that of the CG $(2.0 \pm 3.7)$. The ratio of belonging to the asymptomatic (Ai0) group was higher in the CG (71.4\%) than in the PG (45.7\%). The number of moderate or severe symptoms (DiII and DiIII) was higher in the PG $(37.1 \%)$ than in the CG (2.4\%). The mean value of QoL of the PG $(60.9 \pm 20.1)$ was significantly lower $(\mathrm{p}<0.001)$ than that of the CG $(75.9 \pm 15.3)$.

Conclusions. Results of the study support that patients with Parkinson's disease have a higher incidence of TMD. Using the SF-36, we were able to quantify lower QoL of the PG.

Keywords: Parkinson's disease, temporomandibular joint disorder, quality of life, oral health impact profile, SF-36

\section{Streszczenie}

Wprowadzenie. W stomatologicznej praktyce klinicznej coraz częściej widuje sie pacjentów z zaburzeniami czynności stawu skroniowo-żuchwowego (ang. temporomandibular joint disorder, TMD). Celem badania było ustalenie, czy istnieje zależność między objawami TMD a choroba Parkinsona.

Materiał i metody. W badaniu przekrojowym wzięto pod uwagę anamnestyczne i kliniczne wskaźniki dysfunkcji oraz korelacje związane z jakością życia (kwestionariusz oceny jakości życia SF-36) u pacjentów z chorobą Parkinsona (PG, n=35) i u osób zdrowych (CG, $n=42$ ). Analizę statystyczną przeprowadzono przy użyciu oprogramowania SPSS 24.0.

Wyniki. Średnia wartość uzyskana na podstawie profilu wpływu zdrowia jamy ustnej (ang. Oral Health Impact Profile, OHIP-14) dla PG $(7,0 \pm 7,7)$ była znacznie wyższa $(\mathrm{p}<0,001)$ niż wśród CG $(2,0 \pm 3,7)$. Wskaźnik przynależności do grupy bezobjawowej (Ai0) okazał się wyższy w przypadku GK $(71,4 \%)$ w porównaniu do PG $(45,7 \%)$. Liczba umiarkowanych lub ciężkich objawów (DiII i DiIII) była większa u PG $(37,1 \%)$ aniżeli u CG $(2,4 \%)$. Średnia wartość jakości życia dla PG $(60,9 \pm 20,1)$ była natomiast istotnie niższa $(\mathrm{p}<0,001)$ niż w przypadku CG $(75,9 \pm 15,3)$.

Wnioski. Wyniki badania potwierdzają, że pacjenci z chorobą Parkinsona częściej cierpią z powodu TMD. Dzięki zastosowaniu SF-36 określono ilościowo niższą jakość życia PG.

Słowa kluczowe: choroba Parkinsona, zaburzenie czynności stawu skroniowo-żuchwowego, jakość życia, profil wpływu zdrowia jamy ustnej, SF-36 


\section{Introduction}

The main symptoms of temporomandibular joint dysfunction (TMD) include pain in the joint and surrounding tissues, limited function, and sound effects during movement, such as clicking. The disease's etiology is not fully clarified since numerous circumstances may increase the chance of its development. Therefore, we can assume that some risk factors have not been clarified [1], making the diagnosis difficult [2].

According to some authors, a change in posture may also cause a modification in the temporomandibular joint's biomechanics, resulting in a joint disorder [3]. Parkinson's disease (PD) is a chronic, progressive, neurodegenerative disease. It is caused by damage in the basal ganglia, accompanied by decreased dopamine levels [4]. Primary symptoms include a decrease or slowdown in voluntary movements (hypokinesia, bradykinesia), muscle stiffness, tremor (resting tremor), and gait disturbances, characterized by postural deformities. Due to increased muscle tone, the limbs experience resistance in all directions during bending. The back and core muscles' stiffness can lead to a flexed posture. In PD, motor abnormalities can also be observed in the orofacial regions, resulting in a lack of facial expressions (poker face) and stifling and monotonous speech [5,6]. The most common pathological changes occur in the jaw movements, which affect chewing, speech, and swallowing to the greatest extent [7,8]. Altered motor function may also cause patient-doctor communication difficulties [9]. Regarding TMD development, the correlation between PD and TMD has already been supported by some research. However, we still cannot find significant literature data on the subject. One study showed that patients with tremor generally do not experience a reduced range of jaw motion. While their chewing movements are not impaired, the trajectory of their movements may change. In contrast, the motion trajectory is not impaired in rigid patients, but the speed and range of chewing and movements may decrease [7]. TMD's symptoms can also include the presence of these lesions, raising the possibility of PD causing the dysfunction.

We aimed to examine whether temporomandibular joint dysfunction is more characteristic in PD than a control group. We hypothesized that the symptoms of PD might predispose to temporomandibular joint problems. In our research, we were seeking a correlation between PD and the incidence of TMD.

\section{Material and methods}

The investigations were conducted with PD patients and their concomitant controls in Pécs, Hungary, between February and November 2019. The study included 35 patients treated for PD (Hoehn-YahrScale II-III.), aged $62.9 \pm 9.8$ years, and 42 subjects in the control group with an average age of $61.3 \pm 11.3$ years. We conducted our examinations at the Department of Dentistry, Oral, and Maxillofacial Surgery of the University of Pécs, Hungary. Members of the control group were selected from the out-patients of the Department of Prosthodontics of the University of Pécs, Hungary (12 men and 30 women).

Eligibility criteria for participation in the study included those diagnosed with PD. The lack of tooth pairs required for the Helkimo index measurements was an exclusion criterion, unless they were replaced somehow. Therefore, we initially examined the subjects' tooth status. Likewise, the criteria for the control group was primarily the presence of the teeth in question. We also considered it crucial that their age be approximately the same as that of the PD group studied.

All participants completed the 14-question OHIP-14 (Oral Health Impact Profile) questionnaire. This screening tool covered functional and social limitations, physical and psychological discomfort, and disadvantageous conditions associated with teeth and prosthodontics, and explored the subjective social effects of oral problems [10].

The Helkimo index system was used to examine temporomandibular dysfunction [11-13]. It numerically represents the patient's symptoms to determine the presence and extent of joint dysfunction. This index allows symptom severity classification, and it can be compared with several other variables. The score consisted of an anamnestic and clinical dysfunctional index. The anamnestic index was based on the participants' subjective responses to the questions relating to symptoms. This included sounds detected with jaw function, limited movement, fatigue or pain in the masticatory muscle, and pain around the joint. The anamnestic index had three grades: $\mathrm{Ai} 0$ = no symptoms, $\mathrm{AiI}=$ mild symptoms, $\mathrm{AiI}$ = severe symptoms.

The clinical dysfunction index can be determined by multiple objective measures: jaw dislocation, temporomandibular joint function, and palpation of the temporomandibular joint and masticatory muscle [14]. It includes the maximum opening measurement determined by the distance between the lower and upper incisors' edges when opening the mouth. We added the degree of vertical overbite to the value utilizing a ruler or caliper for the measurements in millimeters. The index included an examination of lateral movement. We drew a vertical mark on the lower and upper incisors in the intercuspal position, and measured the distance between the marks at maximum right and left lateral movements. To examine the mandible's protrusive position, we 
drew a vertical mark on the lower and upper canines in the intercuspal position. We measured the distance between the two lines with the jaw in a forward position [15].

PD is a progressive, neurodegenerative disease, so it is also essential to identify at what stage symptoms are most common. It is also essential to note any connection between deterioration in the quality of life and TMD symptoms development. For the subjective assessment of the quality of life, international literature utilizes numerous indices and questionnaires. For example, the SF-36 questionnaire provides information on patients' physical, psychological, and mental condition. Using SF-36 questionnaires allowed us to compare PD patients' condition with the control group of the same age and investigate the presence of TMD symptoms accordingly. The questionnaire examines eight factors: physical activity, limitations caused by physical and mental health, physical pain, mental and physical health, social activity, and vitality measured through 36 questions [16,17]. These eight main factors were divided into two different groups evaluating overall physical and mental health.

Ethical approval was granted for the study by the Ethics Committee of the University of Pécs (No. 6919). Participation in the research was voluntary, and participants were informed about the research aim and methods before signing the informed consent form. The investigation conforms to the principles outlined in the Declaration of Helsinki.

\section{Statistical analysis}

Statistical data analysis was conducted by SPSS 24.0 statistical software. In addition to descriptive statistics, chi-square tests were used to examine the correlations. Mann-Whitney U and Kruskal-Wallis tests were utilized to analyze the differences between the PD and the control group. Statistical tests were considered significant at $\mathrm{p}<0.05$.

\section{Results}

A total of 77 subjects were enrolled in the study. 43 were female patients, and 34 were male patients with a mean age of $62.0 \pm 10.6$ years. The youngest patient was 40 , and the oldest one was 85 years of age. In our study, we sought to select control patients appropriate for the subjects' age group with PD. Table 1 separately summarizes the oral hygiene habits and oral conditions of both groups.

Table 1. Oral hygiene habits and types of prosthetic restorations in the Parkinson's disease and the control groups

\begin{tabular}{|c|c|c|c|c|c|}
\hline & & \multicolumn{4}{|c|}{ Group } \\
\hline & & \multicolumn{2}{|c|}{ PD } & \multicolumn{2}{|c|}{ Control } \\
\hline & & $\mathbf{n}$ & $\%$ & $\mathbf{n}$ & $\%$ \\
\hline \multirow{3}{*}{$\begin{array}{l}\text { Description of upper } \\
\text { prosthodontics }\end{array}$} & none & 9 & $25.7 \%$ & 8 & $19.0 \%$ \\
\hline & fixed & 17 & $48.6 \%$ & 23 & $54.8 \%$ \\
\hline & removable & 9 & $25.7 \%$ & 11 & $26.2 \%$ \\
\hline \multirow{3}{*}{ Description of lower prosthodontics } & none & 19 & $54.3 \%$ & 24 & $57.1 \%$ \\
\hline & fixed & 10 & $28.6 \%$ & 10 & $23.8 \%$ \\
\hline & removable & 6 & $17.1 \%$ & 8 & $19.0 \%$ \\
\hline \multirow{4}{*}{ Tooth brushing frequency } & not every day & 2 & $5.7 \%$ & 1 & $2.4 \%$ \\
\hline & once a day & 11 & $31.4 \%$ & 12 & $28.6 \%$ \\
\hline & twice a day & 11 & $31.4 \%$ & 24 & $57.1 \%$ \\
\hline & more than twice a day & 11 & $31.4 \%$ & 5 & $11.9 \%$ \\
\hline \multirow{2}{*}{ Smoking } & no & 34 & $97.1 \%$ & 36 & $85.7 \%$ \\
\hline & yes & 1 & $2.9 \%$ & 6 & $14.3 \%$ \\
\hline \multirow{2}{*}{ Oral hygiene aids: toothbrush } & no & 7 & $20.0 \%$ & 5 & $11.9 \%$ \\
\hline & yes & 28 & $80.0 \%$ & 37 & $88.1 \%$ \\
\hline \multirow{2}{*}{$\begin{array}{l}\text { Oral hygiene aids: electric } \\
\text { toothbrush }\end{array}$} & no & 27 & $77.1 \%$ & 33 & $78.6 \%$ \\
\hline & yes & 8 & $22.9 \%$ & 9 & $21.4 \%$ \\
\hline \multirow{2}{*}{ Oral hygiene aids: dental floss } & no & 32 & $91.4 \%$ & 32 & $76.2 \%$ \\
\hline & yes & 3 & $8.6 \%$ & 10 & $23.8 \%$ \\
\hline \multirow{2}{*}{$\begin{array}{l}\text { Oral hygiene aids: interdental } \\
\text { cleaner }\end{array}$} & no & 32 & $91.4 \%$ & 38 & $90.5 \%$ \\
\hline & yes & 3 & $8.6 \%$ & 4 & $9.5 \%$ \\
\hline \multirow{2}{*}{ Oral hygiene aids: mouth rinse } & no & 30 & $85.7 \%$ & 34 & $81.0 \%$ \\
\hline & yes & 5 & $14.3 \%$ & 8 & $19.0 \%$ \\
\hline
\end{tabular}


In our study, as a result of the combined value of the 14-question OHIP-14 questionnaire examining the subjective effects of oral problems, the analyses show that the value of the PD group (7.0 \pm 7.7 ) was significantly

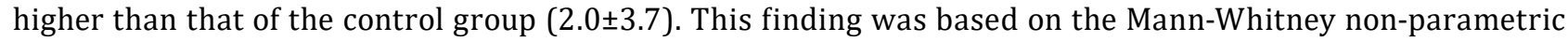
statistical test $(U=371 ; Z=-3.901 ; p<0.001)$. Examining gender differences, we found no significant difference between female and male patients in the PD age group ( $U=99 ; Z=-1.519 ; p>0.05)$. But in the control group, values were significantly higher in women than men $(U=105 ; \mathrm{Z}=-2.393 ; \mathrm{p}<0.05)$.

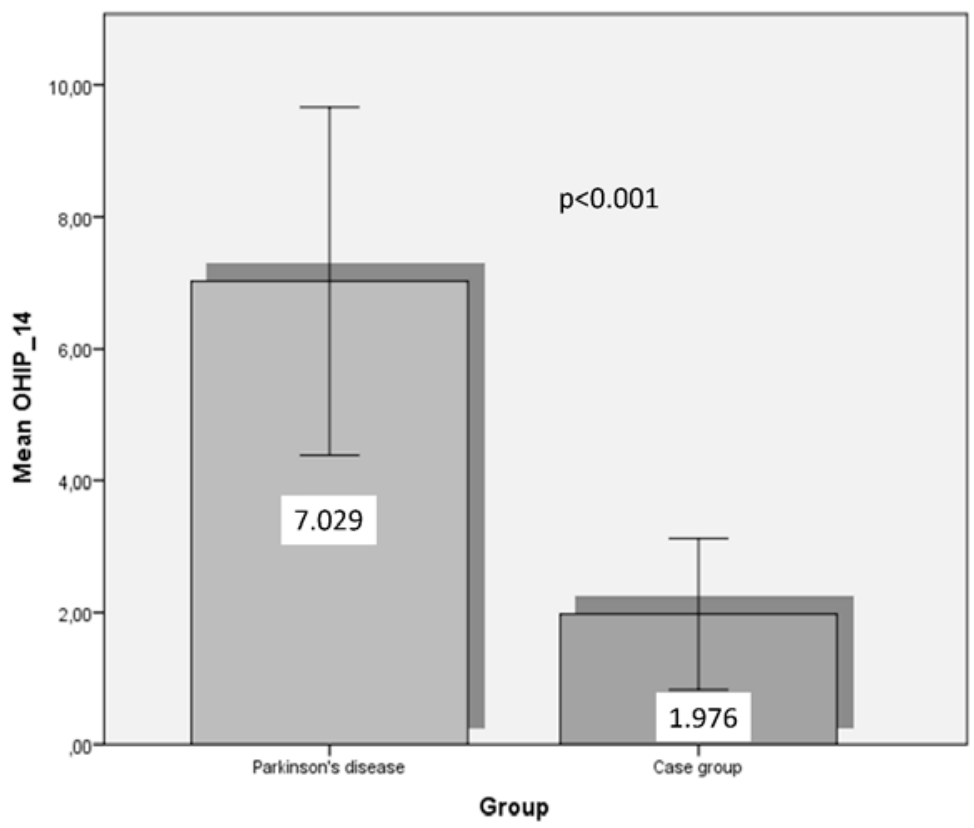

Figure 1. OHIP-14 values in the two groups examined

Investigatingthe subjectiveanamnesticindexoftheHelkimoindexsystemused to examine temporomandibular dysfunction (Table 2), we concluded that the ratio of patients belonging to the asymptomatic (Ai0) group was higher in the control group (71.4\%) than in the PD group (45.7\%).

Table 2. Anamnestic index values

\begin{tabular}{|c|c|c|c|c|}
\hline \multirow{2}{*}{ Anamnestic index } & \multicolumn{2}{|c|}{ PD group } & \multicolumn{2}{c|}{ Control group } \\
\cline { 2 - 5 } & Frequency & Percent (\%) & Frequency & Percent (\%) \\
\hline Ai0 & 16 & 45.7 & 30.0 & 71.4 \\
\hline Ai1 & 13 & 37.1 & 9.0 & 21.4 \\
\hline Ai2 & 6 & 17.1 & 3.0 & 7.1 \\
\hline Total & 35 & 100.0 & 42.0 & 100.0 \\
\hline
\end{tabular}

The values of the Di component obtained from the clinical examinations (Table 3) showed that the number of the patients with moderate and severe symptoms (DiII and DiIII) was significantly higher in the PD group (37.1\%) than in the control group (2.4\%). 52.4\% of the control group was clinically asymptomatic, and 19\% showed mild dysfunction. $14.3 \%$ of the PD group was clinically asymptomatic, while we found moderate dysfunction in $25.7 \%$ compared with only $2.4 \%$ of the control group. Table 4 shows the extent to which the quality of life values of the $\mathrm{PD}$ and control groups differed using the SF-36 questionnaire.

Table 3. Clinical dysfunctional index values

\begin{tabular}{|c|c|c|c|c|}
\hline \multirow{2}{*}{$\begin{array}{c}\text { Clinical } \\
\text { dysfunctional index }\end{array}$} & \multicolumn{2}{|c|}{ PD group } & \multicolumn{2}{c|}{ Control group } \\
\cline { 2 - 5 } & Frequency & Percent (\%) & Frequency & Percent (\%) \\
\hline Di0 & 5 & 14.3 & 22.0 & 52.4 \\
\hline Di1 & 17 & 48.6 & 19.0 & 45.2 \\
\hline Di2 & 9 & 25.7 & 1.0 & 2.4 \\
\hline Di3 & 4 & 11.4 & 0.0 & 0.0 \\
\hline Total & 35 & 100.0 & 42.0 & 100 \\
\hline
\end{tabular}


Table 4. SF-36 index values in the groups examined

\begin{tabular}{|c|c|c|c|c|c|}
\hline \multirow{2}{*}{ Group } & \multicolumn{3}{|c|}{ SF-36 } & p \\
\cline { 2 - 5 } & Mean & $\begin{array}{c}\text { Standard } \\
\text { Deviation }\end{array}$ & $\begin{array}{c}\text { Mann-Whitney } \\
\text { U score }\end{array}$ & Z score & \\
\hline PD group & 60.89 & 20.09 & 404.50 & 3.381 & 0.001 \\
\hline Control Group & 75.85 & 15.29 & 19.05 & & \\
\hline Total & 69.05 & & & \\
\hline
\end{tabular}

There was a significant difference ( $U=404.5 ; \mathrm{Z}=-3.381 ; \mathrm{p}=0.001)$ in the mean of the SF-36 index between PD patients $(60.89 \pm 20.09)$ and the control group (75.85 \pm 15.29$)$ based on the results of the nonparametric MannWhitney test. Examining gender differences, it can be stated that there was no difference in the PD group (U=90; $\mathrm{Z}=-1.810 ; \mathrm{p}>0.05$ ) nor in the control group ( $\mathrm{U}=144 ; \mathrm{Z}=1.002 ; \mathrm{p}>0.05)$.

\section{Discussion}

The study aimed to examine whether TMD is more characteristic in PD than within a control group. It was hypothesized that the symptoms of PD might predispose to TMD problems, too. The correlation between PD and the incidence of TMD was also studied.

PD etiology is still not definitively clarified, and numerous circumstances may increase the likelihood of onset. Therefore, we can assume that undiscovered risk factors may exist [1]. According to some authors, a change in posture may also cause a modification in the biomechanics of the temporomandibular joint and result in a joint disorder [3]. According to Bakke et al., motor abnormalities in the orofacial region in patients with PD may affect the development of TMD [4]. Da Costa Silva et al. found temporomandibular joint abnormalities in only $20.33 \%$ of the 59 PD patients examined. This finding suggests a lower frequency than the results of our present study [18].

While the number of subjects in the target group was low, our hypothesis that patients with PD may have a higher incidence of temporomandibular joint dysfunction appears to be confirmed. Our clinical study showed mild to moderate symptoms in $85.71 \%$ of our subjects, although only approximately half of the patients reported subjective symptoms (AiI and AiII: $54.20 \%$ ). Presumably, other symptoms of the underlying disease hide the involvement of the temporomandibular joint. In our study, we found that in the case of the PD and the control groups, there was no significant difference between them in the anamnestic index (khi2=5.396; $\mathrm{p}>0.005)$. However, in the case of the clinical dysfunction index, the values of the PD patients were significantly higher (khi2=20.571; p<0.001).

Persson et al. investigated thirty patients with PD concerning their oral health [19]. They found that PG had significantly more teeth and less caries than the CG of the corresponding age. However, those with more severe parkinsonian symptoms also presented with lower salivary secretion rates, a difference that was considered significant. The authors concluded that both motor impairment and autonomic dysfunction, as an expression of more advanced neuron degeneration, should be considered essential to maintaining good oral health in PD.

Examining the social effects of oral problems with the OHIP-14 questionnaire, covering functional and social limitations, physical and psychological discomfort, and disadvantageous conditions associated with teeth and prosthetic restorations, we can conclude that patients with PD had significantly higher, i.e., worse values in this study group. Ration of asymptomatic patients (Ai0) was higher in the CG (71.4\%) than in the PG (45.7\%).

In comparison, Barbe et al. explored self-assessed dental care of 100 patients with PD in Germany. They included the ability to perform oral hygiene, self-assessed xerostomia, drooling and dysphagia problems, and the impact on oral health-related QoL. In their study, the Oral Health Impact Profile (OHIP - 14) total score ranged between $14.6 \pm 9.7-16.8 \pm 11.4$ compared to $11.3 \pm 9.9$ in participants without symptoms. $49 \%$ of the participants experienced xerostomia, $70 \%$ drooling, and $47 \%$ dysphagia. Furthermore, $29 \%$ of them suffered from a limited ability to perform oral hygiene [20]. Here, we examined the quality of life value between the two groups with the SF-36 questionnaire. We found that subjects with PD reported a significantly worse quality of life than the control group members.

Bezerra et al. studied the correlation between the oral health status and the QoL in PD. The Decayed, Missing, Filled (DMFT) index and the Parkinson's Disease Questionnaire-39 was used. Sixty-two patients with a clinical diagnosis of PD stages I-III participated in the study. Contrary to our study, we found no correlation between the DMFT values and the total score PDQ-39, neither in its domains nor between the DMFT and PD stages ( $\mathrm{p}=0.61$ ). The authors described deficient oral health in the PG due to the high number of missing teeth. However, their perception of the quality of life was favorable despite motor limitations related to daily living mobility and activities [21]. 
Although new methods are developed for examining and treating TMD [22], we used a traditional, yet practical, method for collecting data and examining patients through the Helkimo index [23]. To the best of our knowledge, our novel study was the first study to apply the Helkimo index to PD patients.

Concerning preventive solutions, the authors would like to emphasize the role of early dental screening and condition assessment for PD patients. Consideration should be given to the collaboration of neurologists, dentists, and physiotherapists in centers managing these patients.

\section{Conclusions}

In summary, we can quantitatively confirm that the subjective quality of life of patients with PD and the social effects due to oral problems significantly influence the control group subjects' results. Our question of whether dysfunction in the temporomandibular joint is more common in patients with PD has been proven in this study group. However, the study's limitation is the small number of patients, so general statements cannot be made.

\section{Disclosures and acknowledgments}

The publication costs were partially funded by the Human Resource Development Operational Program, grant No.: HRDOP-3.6.2-16-2017-00003, Cooperative Research Network in Economy of Sport, Recreation, and Health. The authors declare that the study design; collection, management, analysis, and interpretation of data; writing of the manuscript are independent of Human Resource Development Operational Program. The authors declare that they have no competing interests.

\section{References:}

1. Buescher JJ. Temporomandibular joint disorders. Am Fam Physician. 2007; 76(10): 1477-1482.

2. Máté 0. [Breaking bad news in the pediatric intensive care unit]. Saarbrücken: GlobeEdit. OmniScriptum Publishing Group; 2017 (in Hungarian).

3. Olmos SR, Kritz-Silverstein D, Halligan W, Silverstein ST. The effect of condyle fossa relationships on head posture. Cranio. 2005; 23(1): 48-52. https://doi.org/10.1179/crn.2005.008

4. Bakke M, Larsen SL, Lantrup C, Karlsborg M. Orofacial function and oral health in patients with Parkinson's disease. Eur J Oral Sci. 2011; 119: 27-32. https://doi.org/10.1111/j.1600-0722.2010.00802.x

5. Friedlander A, Mahler M, Norman KM, Ettinger RL. Parkinson disease: systematic and orofacial manifestations, medical and dental management. JADA. 2009; 140(6): 658-669. https://doi.org/10.14219/jada.archive.2009.0251

6. Robertson LT, Hammerstad JP. Jaw movement dysfunction related to Parkinson's disease and partialy modified by levodopa. J Neurol Neurosurg Psychiatry. 1996; 60: 41-50. https://doi.org/10.1136/jnnp.60.1.41

7. Albuquerque LC, Silva HJ. Jaw movement in people with Parkinson's disease. Codas. 2016; 28(2): 193-196. https://doi.org/10.1590/2317-1782/20162015057

8. Cordier R, Brown T, Clemson L, Byles J. Evaluating the longitudinal item and category stability of the SF-36 full and summary scales using Rasch analysis. Biomed Res Int. 2018; 2: 1-30.

9. Máté 0, Brantmüller É. How to break bad news?: Elaboration of a modern practical communication course at the Faculty of Health Sciences of UP, Révkomárom, Szlovákia. Komárno: Selye János University; 2017. p. 139-149.

10. Husain FA, Tatengkeng F. Oral health-related quality of life appraised by OHIP-14 between urban and rural areas in Kutai Kartanegara Regency, Indonesia: pilot Pathfinder Survey. Open Dent J. 2017; 11: 557-564. https://doi.org/10.2174/1874210601711010557

11. Rani S, Pawah S, Gola S, Bakshi M. Analysis of Helkimo index for temporomandibular disorder diagnosis in the dental students of Faridabad City: a cross-sectional study. J Indian Prosthodont Soc. 2017; 17: 48-52.

12. Szentpétery A, Fazekas A, Rudas K. [A standardized method for the epidemiological and clinical investigation of functional jaw disease]. Fogorv Szle. 1986; 79: 21-25 (in Hungarian).

13. Szentpétery A, Fazekas A, Rudas K. [Investigation of the epidemiology of temporomandibular pain dysfunction syndrome in dentistry students]. Fogorv Sz. 1986; 79: 193-198 (in Hungarian).

14. Beddis HP, Davies SJ, Budenberg A, Horner K, Pemberton MN. Temporomandibular disorders, trismus and malignancy: development of a checklist to improve patient safety. Br Dent J. 2014; 217(7): $351-355$. https://doi.org/10.1038/sj.bdj.2014.862 
15. Angyal J. [Diagnosis and therapy of temporomandibular diseases]. Fogorv Sz. 2002; 95(5): 181-188 (in Hungarian).

16. Brazier JE, Harper R, Jones NM, O'Cathain A, Thomas KJ, Usherwood T, et al. Validating the SF-36 health survey questionnaire: new outcome measure for primary care. BMJ. 1992; 305(6846): 160-164. https://doi.org/10.1136/bmj.305.6846.160

17. Czimbalmos Á, Nagy Z. [Patients' satisfaction survey with SF-36 questionnaire, determination of normal values in Hungary]. Népegészségügy. 1999; 80(1): 4-19 (in Hungarian).

18. da Costa Silva PF, Biasotto-Gonzalez DA, Motta LJ, Silva SM, Ferrari RAM, Fernandes KPS, et al. Impact in oral health and the prevalence of temporomandibular disorder in individuals with Parkinson's disease. J Phys Ther Sci. 2015; 27(3): 887-891. https://doi.org/10.1589/jpts.27.887

19. Persson M, Sterberg TÖ, Granérus AK, Karlsson S. Influence of Parkinson's disease on oral health. Acta Odontol Scand. 1992; 50(1): 37-42. https://doi.org/10.3109/00016359209012744

20. Barbe AG, Bock N, Derman SHM, Felsch M, Timmermann L, Noack MJ. Self-assessment of oral health, dental health care and oral health-related quality of life among Parkinson's disease patients. Gerodontology. 2017; 34(1): 135-143. https://doi.org/10.1111/ger.12237

21. Bezerra PGT, de Andrade Veras SR, da Silva CC, da Silva RM, da Silva DEP, da Costa Leite EB, et al. The quality of life for people with Parkinson's disease in relation to their oral health. Open J Stomatol. 2018; 8(11): 312318. https://doi.org/10.4236/ojst.2018.811029

22. Barath Z, Rasko Z. Technique for achieving a stable position of the condylar process during injection into the temporomandibular joint. Br J Oral Maxillofac Surg. 2020; 58(1): 92-95.

https://doi.org/10.1016/j.bjoms.2019.09.004

23. Baumann P, Marada G, Jahani M, Radnai M. [Investigation of the incidence of temporomandibular joint disorder in patients with Parkinson's disease]. Fogorv Sz. 2018; 111(1): 2-5 (in Hungarian). 